\title{
Hide Dehairing and Laundry Detergent Compatibility Testing of Thermostable and Solvents Tolerant Alkaline Protease from Hot Spring Isolate Bacillus cohniiU3
}

\author{
${ }^{1}$ Pravin R. Dudhgara, ${ }^{2}$ Bhavsar Sunil and ${ }^{3}$ Ghelani Anjana \\ ${ }^{I}$ Department of Biotechnology, Veer Narmad South Gujarat University, Surat-395007, Gujarat, India \\ ${ }^{2}$ Department of Biosciences, Veer Narmad South Gujarat University, Surat-395007, Gujarat, India \\ ${ }^{3}$ Department of Microbiology, \\ Shree Ramakrishna Institute of Computer Education and Applied Sciences, Surat-395001, Gujarat, India
}

\author{
Article history \\ Received: 20-06-2014 \\ Revised: 25-10-2014 \\ Accepted: 22-07-2015 \\ Correspondence Author: \\ Pravin R. Dudhgara \\ Department of Biotechnology, \\ Veer Narmad South Gujarat \\ University, Surat-395007, \\ Gujarat, India \\ E-mail: dudhagarapr@gmail.com
}

\begin{abstract}
In the present study, alkaline protease producing thermophilic Bacillus cohniiU3 strain was isolation from Unnai hot spring, India. The maximum production of protease $(344 \mathrm{U} / \mathrm{mL})$ was reported after $72 \mathrm{~h}$ of inoculation at $50^{\circ} \mathrm{C}$ in shake flask culture using the gelatin casein medium. The protease was found to remain active up to $96 \mathrm{~h}$ and production was growth dependent. The activity of parital purified protease was reported in abroad range of $\mathrm{pH}$ ranging from 4.0 to 11.0 with an optimum of $9.0 \mathrm{pH}$; Enzymes was indicated the highest activity at $50^{\circ} \mathrm{C}$ temperature. Salt independent catalysis and activity with a broad range of substrate concentration is the key feature of the protease. Thermos table nature, the stability in alkaline $\mathrm{pH}$ and stability in high salt concentration for $45 \mathrm{~min}$ were outstanding features of protease. The enzyme was stable in the presence of various organic solvents like Dimethyl Sulphoxide (DMSO), Methanol, Butanol, $\mathrm{n}$-Hexane, Benzene at 25\% (v/v) concentration. A good compatibility of the enzyme with most commercial detergents indicated its application in detergent industry. The remarkable dehairing in goat hide and destaining of blood spot in $2 \mathrm{~h}$ using $10 \mathrm{U} / \mathrm{mL}$ of protease assure that it could be a potential candidate for leather and detergent industries.
\end{abstract}

Keywords: Alkaline Protease, Bacillus cohnii, Hot Spring, Solvent Tolerant, Detergent Compatible, Hide Dehairing

\section{Introduction}

With an increasing emphasis on environmental protection, the use of hydrolytic enzymes particularly from thermophiles, has gained significant attention in many industrial processes. Enzymes from thermophiles are of particular interest since the high temperature does not usually denature them and remain active at elevated temperature (Adams and Kelly, 1998). Furthermore, they are more resistant to chemical reagents and extreme $\mathrm{pH}$ in comparison to their mesophilic homologues (Hough and Denson, 1999). Their thermostability is associated with performing the enzymatic reaction at high temperature allows higher substrate concentrations, lower viscosity, the fewer risk of contamination and often higher reaction rates (Seatovic et al., 2004). Therefore, thermophiles were the promising choice for massive enzyme production for industrial applications. Global requirements of thermostable biocatalysts are far greater than those of the mesophilic biocatalysts suggesting the huge need of thermophilic enzymes (Haki and Rakshit, 2003).

Thermophilic bacteria have gained a significant attention to industrial scale. Microbiologists are more interested in thermophilic bacteria as a natural source of enzymes that are active and stable at elevated temperatures. Hot springs are the rich source for the thermophilic bacteria for the direct isolation of thermostable enzymes (Olajuyigbe and Kolawole, 2011). Recently, fewhot spring isolated thermophilic Bacillus species are well studied for the alkaline protease production including, Bacillus licheniformis (Dudhagara et al., 2014), Bacillus subtilis (Priya and Archana, 2008) and Geobacillus sp. (Wei et al., 2007).

Bacillus species are the main producers of extracellular proteases (Pant et al., 2015). Use of the Bacillus species for protease offers several advantageous like significant activity, stability, substrate specificity, 
short period of fermentation, mere downstream purification and low cost production (Maurer, 2004; Anissa et al., 2009; Hazem et al., 2012).

Thermostability is the crucial properties of enzyme for industrial application. The application of thermostable enzymes offers higher reaction rates, increased half-life and operational stability, increased the resistance towards organic solvents and lower contamination risks during fermentation.

Proteases are the single class of enzymes which occupy a pivotal position with respect to their wide applications in commercial fields. Protease is widely employed as technical grade enzymes in various industrial processes. The largest consumption of protease is in laundry detergent and leather industries (Banerjee et al., 1999). In detergent industries, alkaline proteases are employed as cleansing additives and preferably, proteases should be stable in detergents and at a broad range of $\mathrm{pH}$ and temperature (Gupta et al., 2002). Enzymatic dehairing is being increasingly looked upon as a reliable alternative to the conventional lime-sulphide process, to avoid the problems created by the sulphide pollution (Paliwal et al., 1994).

In the present study, we had isolate and identify the proteolytic thermophilic Bacillus cohniiU3 from Unai hot spring, Gujarat state, India. The study also probed enzyme's suitability through characterization for the biotechnological purpose, especially for the detergent and leather industries.

\section{Materials and Methods}

\section{Isolation and Identification of Bacteria}

Isolation of strain was carried out by the enrichment of water collected from Unnai hot spring $\left(20^{\circ} 85^{\prime} 33^{\prime \prime} \mathrm{N}\right.$, $73^{\circ} 33^{\prime} 42^{\prime \prime} \mathrm{E}$ ), India into Gelatin Casein (GC) broth containing $\mathrm{g} / \mathrm{L}$ : gelatin, 5.0 ; casein enzymatic hydrolysate, 1.0; peptone, 5.0; yeast extract, 1.5; meat extract, $1.5 ; \mathrm{NaCl}, 5.0 ; \mathrm{pH} 7.5$ followed by incubation at $50^{\circ} \mathrm{C}$ for $48 \mathrm{~h}$ under shake flask conditions. After $48 \mathrm{~h}$, a loop full of culture was streaked on same solid medium and incubated at $50^{\circ} \mathrm{C}$. Protease production was detected by plate assay. Strain U3 was identified by $16 \mathrm{~s}$ rRNA gene sequencing. The gene sequence was submitted to NCBI nucleotide database with accession number GU979027.1.

\section{Protease Production and Partial Purification}

The inoculum was developed by inoculating a single colony of isolateinto $25 \mathrm{~mL}$ of sterile GC medium $\mathrm{pH}$ 7.5 and incubated at $50^{\circ} \mathrm{C}$ on a shaker for $24 \mathrm{~h}$. A $10 \%$ inoculum $\left(\mathrm{A}_{660 \mathrm{~nm}}: 1.0\right)$ was added to $\mathrm{GC}$ broth $(\mathrm{pH} 7.5)$ and incubated for $96 \mathrm{~h}$ at $50^{\circ} \mathrm{C}$ under shaking condition (120 rpm). Growth was measured colorimetrically at 660 $\mathrm{nm}$ and culture was harvested by centrifugation at 8000 rpm for $10 \mathrm{~min}$ at $5^{\circ} \mathrm{C}$. The cell-free extract was used as crude preparation to measure protease activity. Partial purification of the protease was done using 70\% saturation of anhydrous Ammonium sulphate followed by dialysis. The partial purified protease was used for further experiments throughout the study.

\section{Protease Assay}

Protease activity was measured by Anson-Hagihara's method using the $0.6 \%$ casein as a substrate (Hagihara, 1958). One unit of protease activity was defined as the amount of enzyme liberating one $\mu \mathrm{g}$ of tyrosine/min under standard assay conditions. Enzyme units were measured using tyrosine ( 0 to $100 \mu \mathrm{g}$ ) as standard.

\section{Growth Profile of Protease Secretion}

The kinetics of growth with enzyme secretion in the GC broth was performed to arrest the maximum enzymesecretion time. Enzymes activity and growth were measured up to $96 \mathrm{~h}$ at every $6 \mathrm{~h}$ regular interval.

\section{Effect of pH, Temperature, Salt and Substrate on Protease Activity}

In order to investigate the influence of $\mathrm{pH}$ on protease activity, $0.5 \mathrm{~mL}$ of protease was added to 3.0 $\mathrm{mL}$ of $0.6 \%$ casein prepared in $20 \mathrm{mM}$ Acetate buffer (pH 4.0 and 5.0), $20 \mathrm{mM}$ Phosphate buffer (pH6.0, 7.0 and 8.0 ) and $20 \mathrm{mM}$ Borax-NaOH buffer ( $\mathrm{pH} 9.0,10.0$ and 11.0$)$. The enzyme activity $(\mathrm{U} / \mathrm{mL})$ was measured as per the standard enzymes assay mentioned as earlier. The effect of temperature on protease activity was examined at various temperatures by incubating enzyme reaction mixtures for $10 \mathrm{~min}$ at different temperatures including $25,30,35,40,45,50,55$ and $60^{\circ} \mathrm{C}$ afterword enzyme activity was measured. To study the effect of salt, 0 to $1 \%, \mathrm{w} / \mathrm{v}$ of $\mathrm{NaCl}$ was added into enzyme reactions and protease assay was performed. The substrate effect on protease activity was determined by taking the 0.2 to $2 \%$ $\mathrm{w} / \mathrm{v}$ of casein concentrations that was prepared in phosphate buffer $\mathrm{pH}$ 7.5. The activity of the enzyme was measured as described previous.

\section{Stability of $p H$, Temperature and Salt on Protease Activity}

The protease was preincubated at three different $\mathrm{pH}$ i.e., 5.0 (acidic), pH 7.0 (neutral) and pH 9.0 (alkali) at $50^{\circ} \mathrm{C}$ for $45 \mathrm{~min}$. The enzyme assay was carried out after 15,30 and $45 \mathrm{~min}$ interval under standard assay conditions and residual activity were measured. Thermostability of protease was measured by preincubation of the protease up to $45 \mathrm{~min}$ at $25^{\circ} \mathrm{C}$ to $60^{\circ} \mathrm{C}$ and residual activity of the enzyme was calculated using standard assay. Salt pretreatment was given to the protease using 0 to $1 \% \mathrm{w} / \mathrm{v} \mathrm{NaCl}$ concentration followed by the incubation up to $45 \mathrm{~min}$ and residual enzyme activity was determined by assay. 


\section{Solvent Stability of Protease}

Five organic solvents including DMSO, Methanol, Butanol, n-Hexane, Benzene along with Distilled water were used for solvent stability. One $\mathrm{ml}$ of $25 \% \mathrm{v} / \mathrm{v}$ organic solvent was added to $3.0 \mathrm{~mL}$ of the protease in screw-capped tubes and incubated at $30^{\circ} \mathrm{C}$ in ashaker at $120 \mathrm{rpm}$ up to 5 days. Enzyme activity was measured at defined time interval under standard assay condition. Stability is expressed as the remaining proteolysis activity relative to the activity in the presence of distilled water (Geok et al., 2003).

\section{Compatibility of Protease with Commercial Detergents}

The Protease was pre-treated with $0.7 \%$, w/v of commercial detergents including Ariel, Tide, Surf excel, Rin and Wheel and residual activity was measured after 15,30 and $60 \mathrm{~min}$.

\section{Digestion of Natural Proteins}

Fresh goat hide purchased from the local market was prewashed with $1 \%$ formaldehyde and sterile distilled water. The hide was cut in $2 \times 2 \mathrm{~cm}$ size and incubated with the $10 \mathrm{U} / \mathrm{mL}$ protease in phosphate buffer $(\mathrm{pH} 8)$ at $50^{\circ} \mathrm{C}$ for two hours. Similarly, $10 \mathrm{U} / \mathrm{mL}$ protease was incubated with blood saturated cloth and incubated at $50^{\circ} \mathrm{C}$ for two hours. Natural proteins hydrolysis observed at regular time interval.

\section{Results}

\section{Isolation and Identification of Organism}

U3 strain was optimally grown at $\mathrm{pH} 8.0$ at $50^{\circ} \mathrm{C}$ temperatureon $\mathrm{GC}$ media. The isolate was Grampositive, road shape, aspore-forming bacterium. Isolate was identified as a moderate thermophilic Bacillus cohnii by 16s rRNA sequence analysis. The BLASTn result shows the 99\% similarity with Bacillus cohnii strain GS47 (accession number KP053306.1). The 16S rRNA gene sequence-based phylogeny is presented in Fig. 1.

\section{Protease Production and Optimization}

After $12 \mathrm{~h}$, the isolate indicates the exponential growth and it maintains up to $66 \mathrm{~h}$ followed by a stationary phase. Maximum biomass was reported at 72 $\mathrm{h}$ and protease secretion corresponded with the growth. The highest enzymes secretion was found $344 \mathrm{U} / \mathrm{mL}$ at the interphase of the late exponential to early stationary phase (Fig. 2). Enzymes activity after the $72 \mathrm{~h}$ was found to slightly decrease due to the proteolysis of enzymes. Production medium after $42 \mathrm{~h}$ appeared very dense and turned in dense yellow color due to the high concentration of biomass and enzyme.

\section{Characterization of Protease}

\section{Effect of pH, Temperature, Salt and Substrate on Protease Activity}

The protease was optimally active at alkaline $\mathrm{pH}$ with maximum activity $(255.25 \mathrm{U} / \mathrm{mL})$ at $\mathrm{pH} 9.0$ and showed low activity at less than $9.0 \mathrm{pH}$ values. Protease activity at $\mathrm{pH} 10$ was $203.85 \mathrm{U} / \mathrm{mL}$ that is double than the activity at $\mathrm{pH} 7.0$ Moreover the activity at $\mathrm{pH} 4.0$ and 5.0 is very less. So it is clear that the enzymeis alkaline protease required the alkaline $\mathrm{pH}$ for the catalysis. Protease was found to active in wide range of temperature; however the optimum activity (169.20 $\mathrm{U} / \mathrm{mL}$ ) was reported at $50^{\circ} \mathrm{C}$ and nearly identical activity $(155.0 \mathrm{U} / \mathrm{mL})$ at $55^{\circ} \mathrm{C}$. The protein catalysis between $35^{\circ} \mathrm{C}$ to $55^{\circ} \mathrm{C}$ was reported maximum. The enzyme appears thermo-active as there was better catalysis at $60^{\circ} \mathrm{C}$ than the $25^{\circ} \mathrm{C}$ temperature. The protease was optimally active in the absence of the salt, however activity of the enzyme was marginally declined to $0.2 \%$ $(\mathrm{w} / \mathrm{v}) \mathrm{NaCl}$ and the further increase the salt concentrations led to the significant reduction in the activity. The optimum requirement of the substrate was reported $0.6 \% \mathrm{w} / \mathrm{v}$, less than $0.6 \%$ dramatically decreases the activity. More than optimum substrate was also inhibited the enzymes activity and negligible activity was reported at $1 \%$ substrate (Table 1 ).

\section{Stability of $p H$, Temperature and Salt on Protease Activity}

Protease was stable for prolonged time and maintaining over $85 \%$ of its original activity at $\mathrm{pH} 5.0$, 7.0 and 9.0 during $30 \mathrm{~min}$ incubation followed by decreasing activity with increasing incubation at each $\mathrm{pH}$ (Fig. 3). The protease was retained nearly $70 \%$ of activity after $45 \mathrm{~min}$ incubation at each temperature ranging from $25^{\circ} \mathrm{C}$ to $55^{\circ} \mathrm{C}$. At $60^{\circ} \mathrm{C}$ protease activity was drastically reduced (Fig. 4). Prolong incubation decreased the enzyme activity. Loss of activity was high at low temperature. The enzyme was found to unstable in the presence of salt as the maximum stability was found in the absence of salt. Stability of the enzyme was decreased by an increase the incubation time at each tested salt concentration. In $1 \%$ salt concentration after 30 min only $62 \%$ activity was remained (Fig. 5).

\section{Solvent Stability of Protease}

Protease showed remarkable stability in all tested solvents. Very less reduction in enzyme stability was reported after $24 \mathrm{~h}$ incubation in the presence of all solvents except benzene. After 5 days' incubation, stability in the presence of n-Hexane and DMSO were more than 92 and $85 \%$ respectively. Greater than $70 \%$ activity was found after 3 days' incubation with all the solvents (Table 2). 


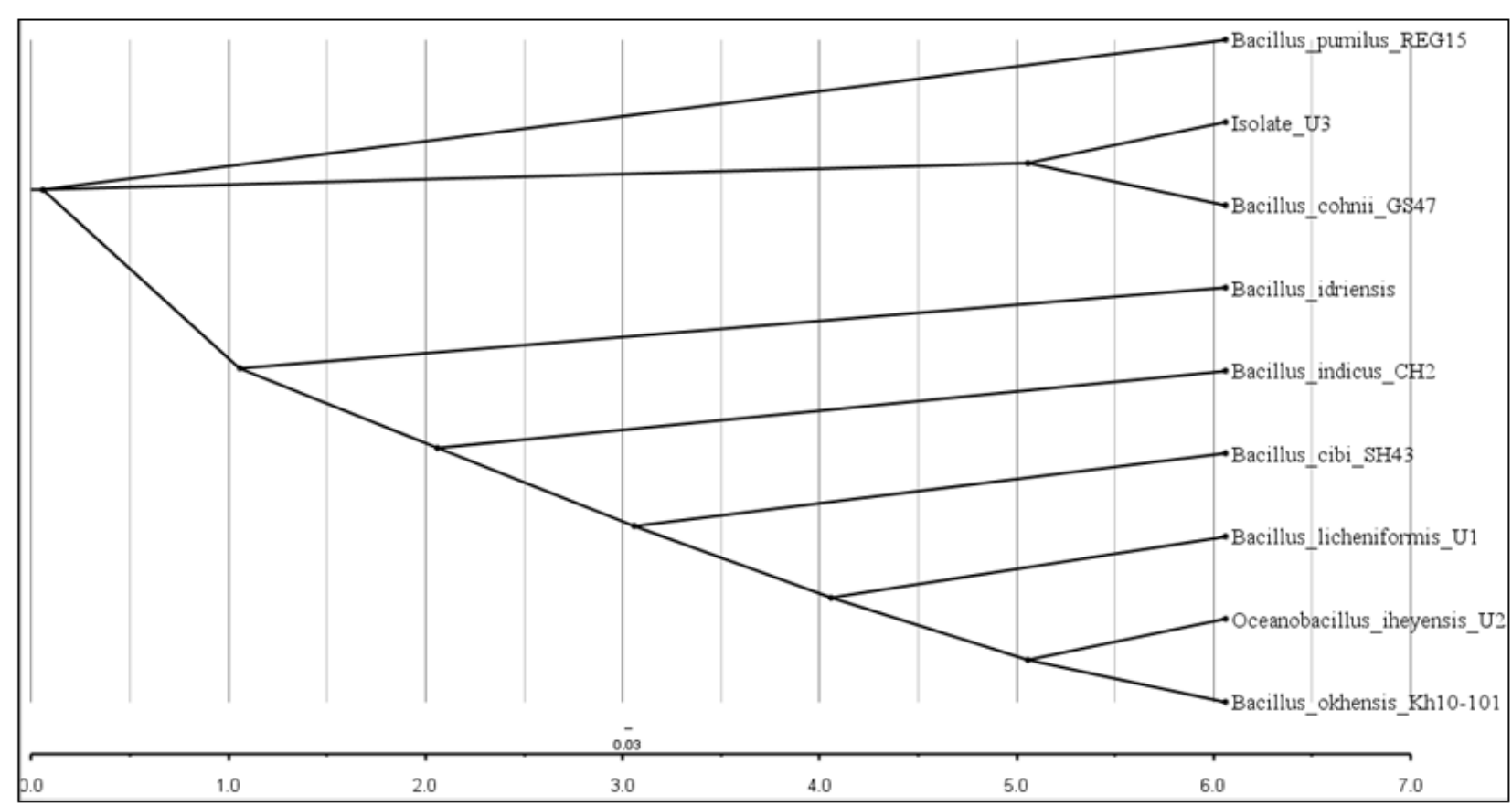

Fig. 1. 16S rRNA gene sequence based phylogenetic analysis of Bacillus cohnii strain U3. The phylogenetic tree constructed by the neighbor-joining method using ClustalW2 showing the position of isolate U3 with scale axis

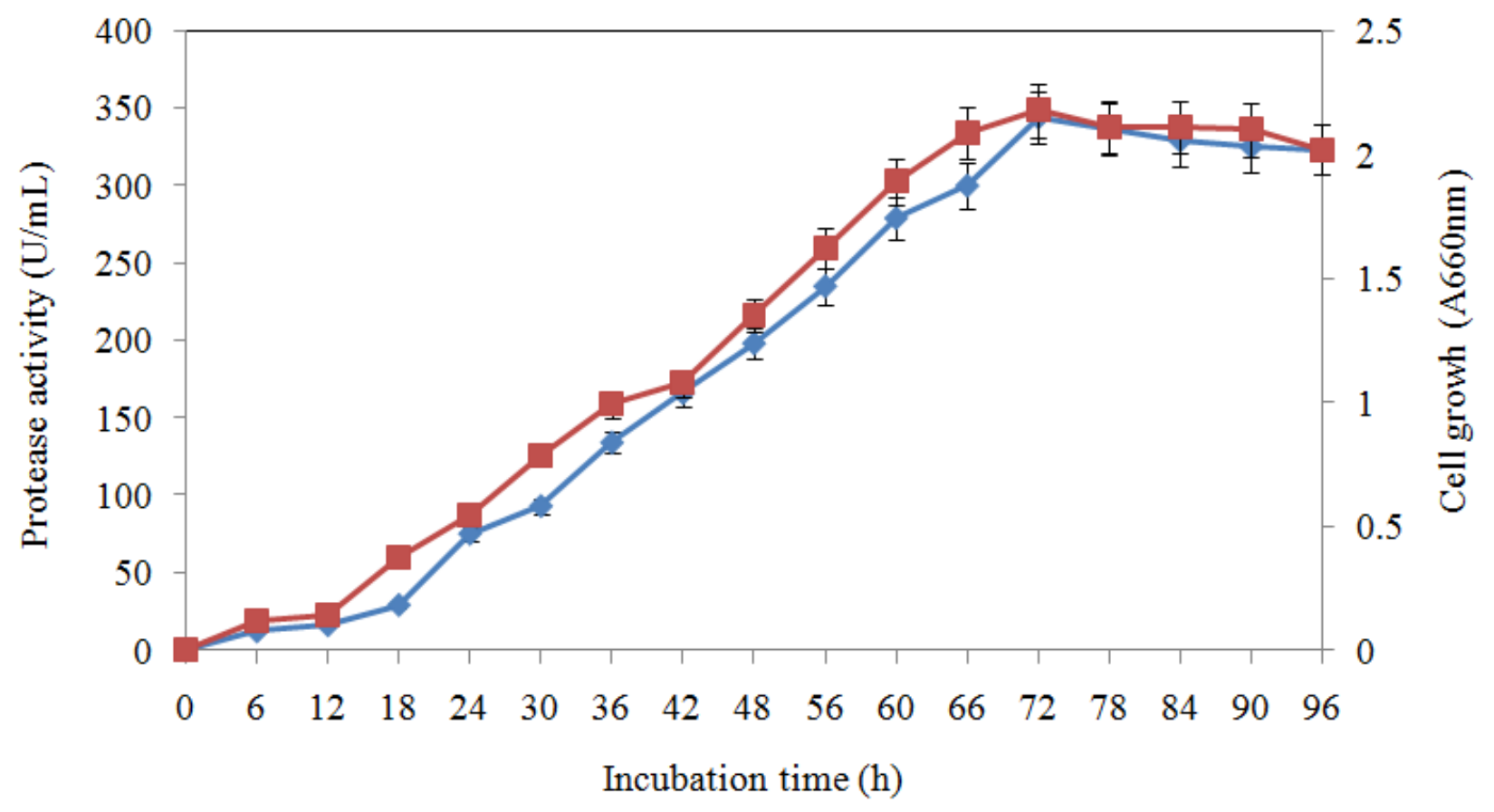

$\rightarrow$ Protease activity $(\mathrm{U} / \mathrm{ml}) \quad \rightarrow$ Cell growth $(\mathrm{A} 660 \mathrm{~nm})$

Fig. 2. Growth profile of Bacillus cohnii strain U3. The bacterium was grown in gelatin casein medium as described in text. Samples were withdrawn aseptically at every $6 \mathrm{~h}$ interval for the determination of cell growth and protease activity. Results represent the means of three experiments and bars indicate \pm standard deviation. Absence of bars indicates that errors were smaller than symbols 


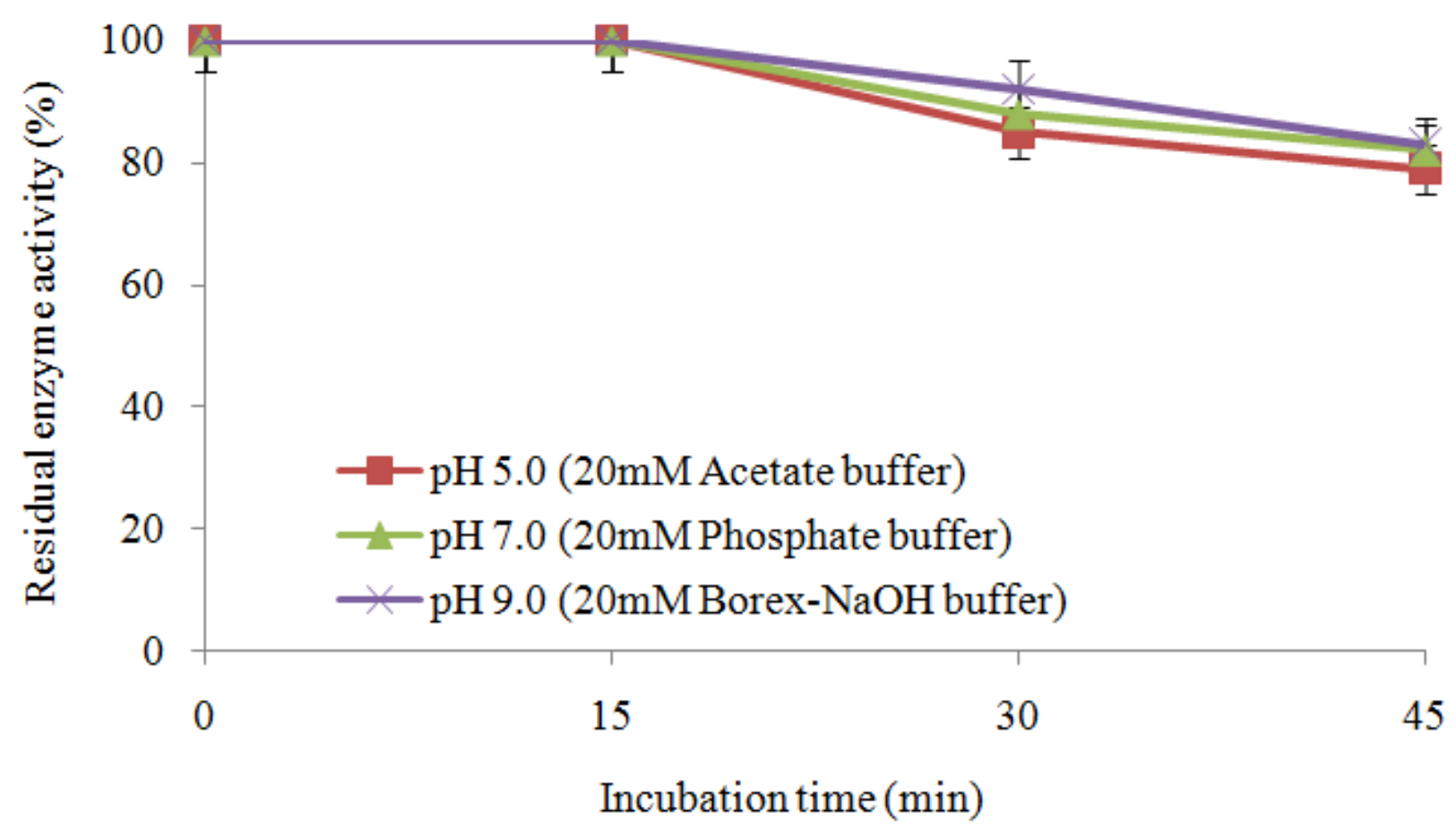

Fig. 3. Effect of $\mathrm{pH}$ on the stability of the protease. The enzyme was pre-incubated at 5.0, 7.0 and $9.0 \mathrm{pH}$ and residual activity was determined from 0 to $45 \mathrm{~min}$ at $15 \mathrm{~min}$ intervals. Activity of protease after $15 \mathrm{~min}$ was considered as the control (100\%). Results represent the means of three experiments and bars indicate \pm standard deviation

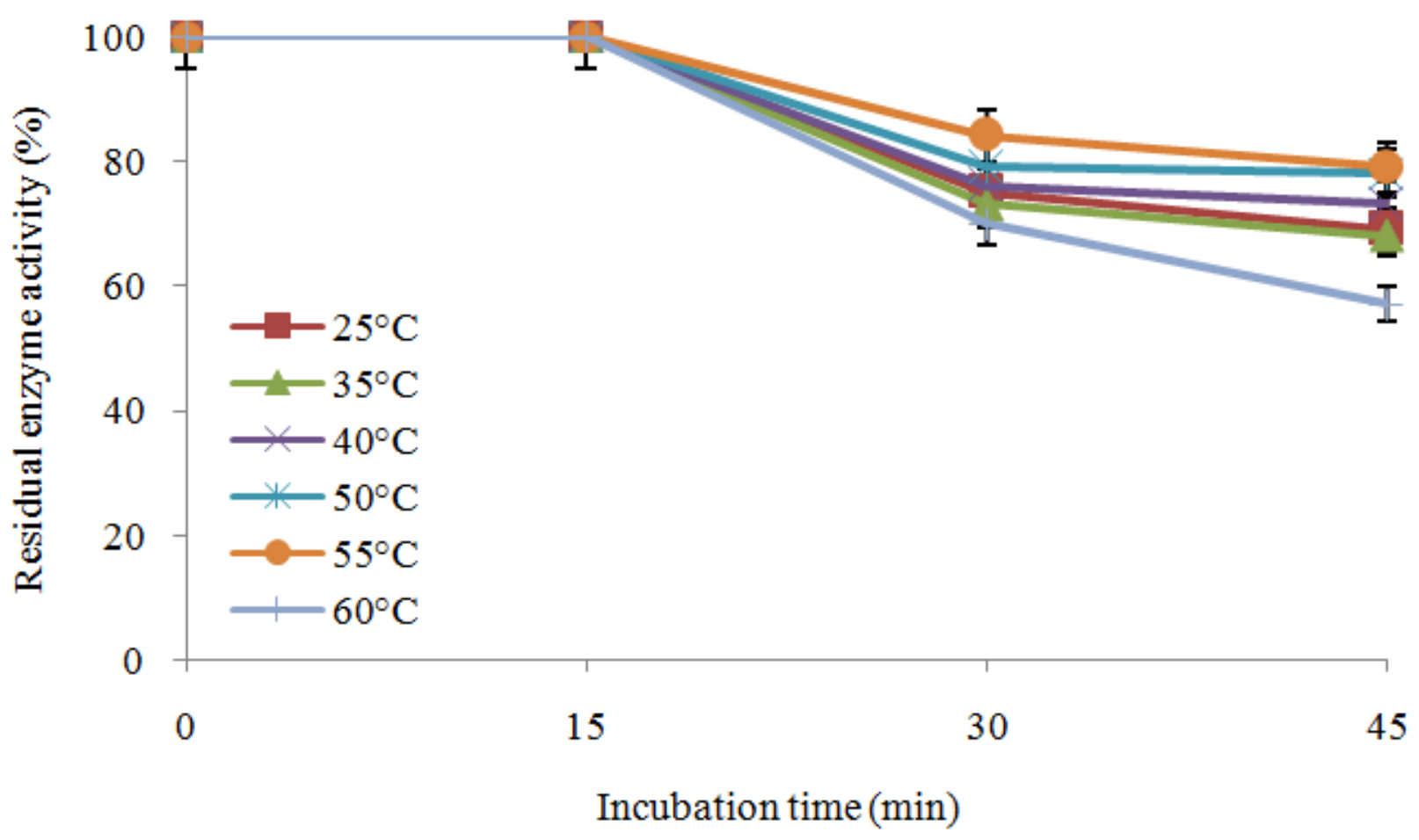

Fig. 4. Effect of temperature on the stability of the protease. The enzyme was pre-treated at $25,35,40,50,55$ and $60^{\circ} \mathrm{C}$ and residual activity was determined from 0 to $45 \mathrm{~min}$ at $15 \mathrm{~min}$ intervals. The activity of protease after 15 min was considered as the control $(100 \%)$. Results represent the means of three experiments and bars indicate \pm standard deviation 


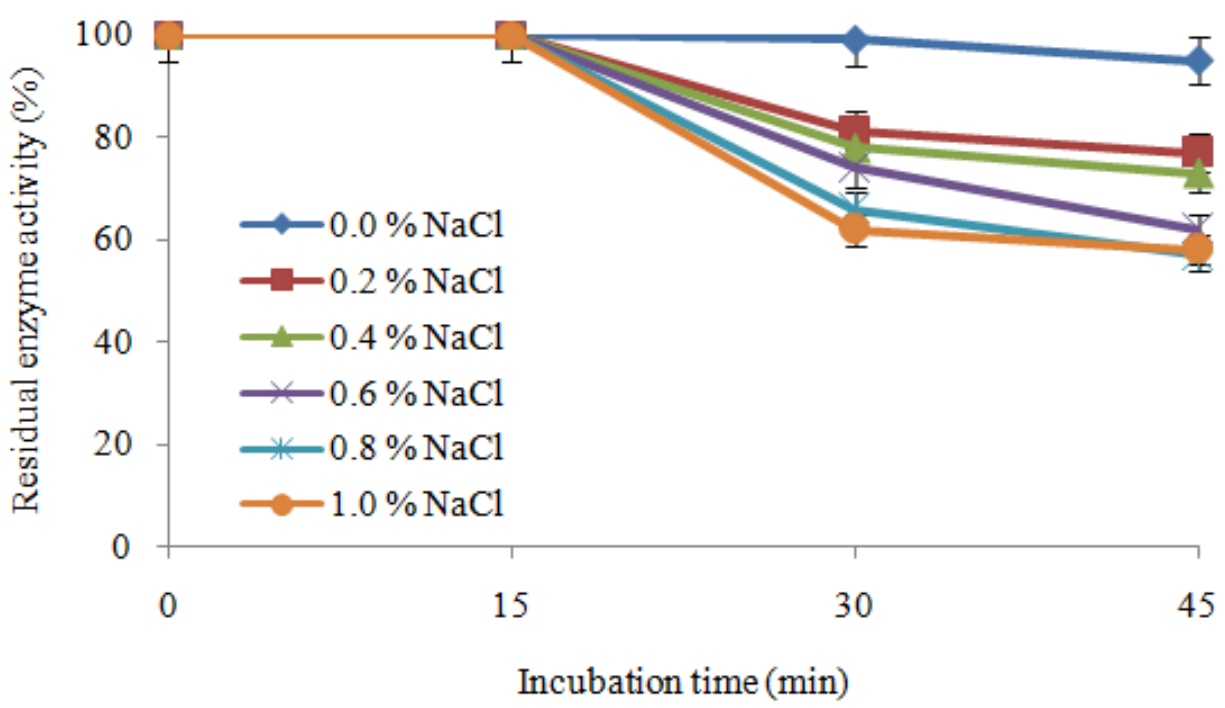

Fig. 5. Effect of $\mathrm{NaCl}$ concentration (\%) on the stability of the protease. The enzyme was pre-treated at 0.0 to $1.0 \%$ salt concentration and residual activity was determined from 0 to $45 \mathrm{~min}$ at $15 \mathrm{~min}$ intervals. The activity of protease after $15 \mathrm{~min}$ was considered as the control $(100 \%)$. Results represent the means of three experiments and bars indicate \pm standard deviation
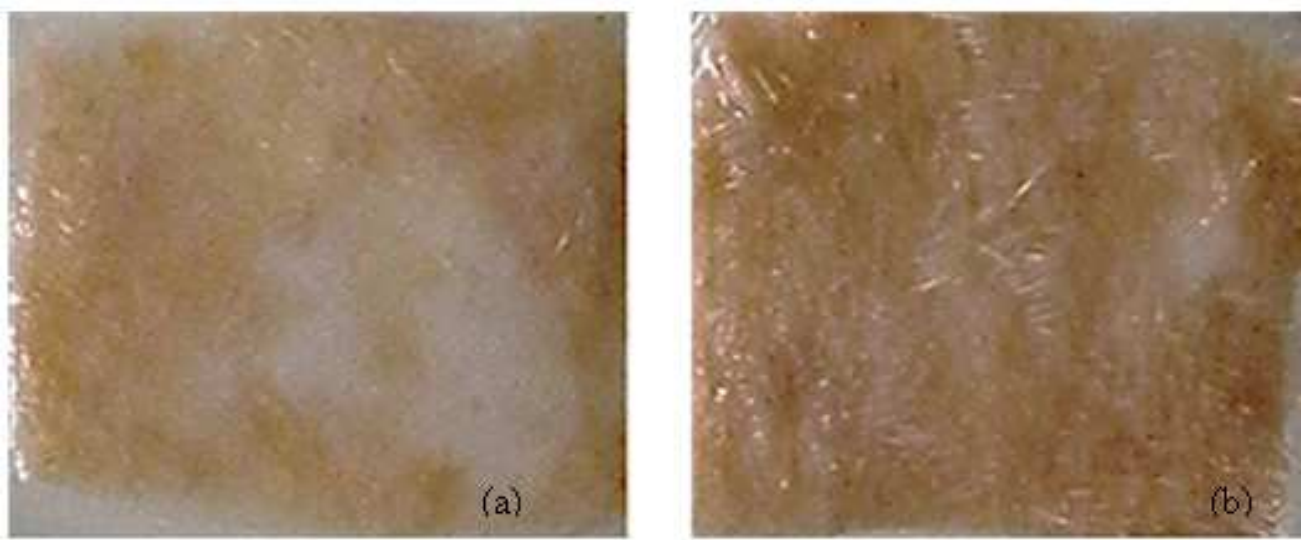

Fig. 6. Dehairing of goat hides (a) Protease treated $(10 \mathrm{U} / \mathrm{mL}$ ) hide showing dehairing (b) No dehairing in control (without protease) hide

(a) $0 \mathrm{~min}$.
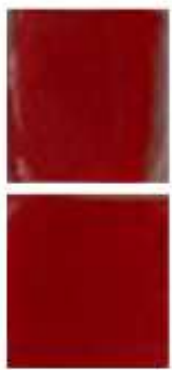

(b) $0 \mathrm{~min}$.

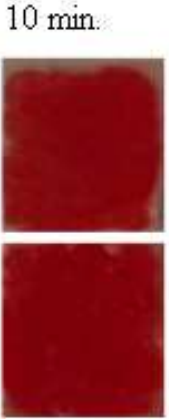

$10 \mathrm{~min}$.
$20 \mathrm{~min}$.
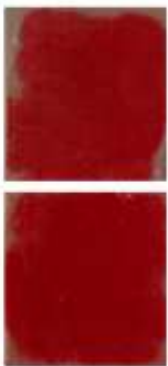

$20 \mathrm{~min}$
$30 \mathrm{~min}$
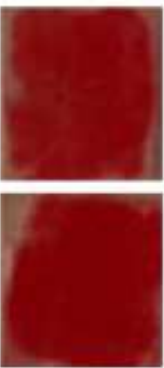

$30 \mathrm{~min}$.
$45 \mathrm{~min}$
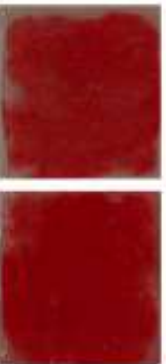

$45 \mathrm{~min}$.

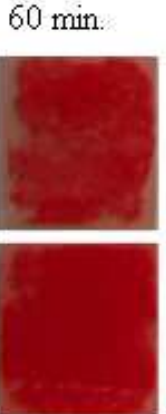

$60 \mathrm{~min}$.
$120 \mathrm{~min}$.

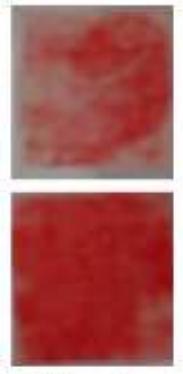

$120 \mathrm{~min}$

Fig. 7. Destaining of blood on cloths (a) Protease treated $(10 \mathrm{U} / \mathrm{ml})$ cloth showing the removal of blood (b) negligible removal of blood showed in control (without protease) 
Table 1. Effects of $\mathrm{pH}$, temperature, salt and substrate on protease activity. It values in the table represent the mean of three experiments

\begin{tabular}{|c|c|c|}
\hline Physico-Chemical Parameters & Scale & Enzyme activity $(\mathrm{U} / \mathrm{mL})$ \\
\hline \multicolumn{3}{|l|}{$\mathrm{pH}$} \\
\hline & 4.0 & 44.10 \\
\hline & 5.0 & 75.15 \\
\hline & 6.0 & 89.55 \\
\hline & 7.0 & 93.15 \\
\hline & 8.0 & 155.25 \\
\hline & 9.0 & 255.15 \\
\hline & 10.0 & 203.85 \\
\hline & 11.0 & 99.45 \\
\hline \multicolumn{3}{|l|}{ Temperature $\left({ }^{\circ} \mathrm{C}\right)$} \\
\hline & 25.0 & 75.15 \\
\hline & 35.0 & 109.35 \\
\hline & 40.0 & 134.55 \\
\hline & 50.0 & 169.20 \\
\hline & 55.0 & 155.00 \\
\hline & 60.0 & 94.50 \\
\hline \multicolumn{3}{|l|}{$\mathrm{NaCl}(\% \mathrm{w} / \mathrm{v})$} \\
\hline & 0.0 & 297.00 \\
\hline & 0.2 & 244.35 \\
\hline & 0.4 & 144.00 \\
\hline & 0.6 & 104.40 \\
\hline & 0.8 & 81.00 \\
\hline & 1.0 & 31.50 \\
\hline \multicolumn{3}{|l|}{ Substrate $(\% \mathrm{w} / \mathrm{v})$} \\
\hline & 0.2 & 49.95 \\
\hline & 0.4 & 58.05 \\
\hline & 0.6 & 144.45 \\
\hline & 0.8 & 113.85 \\
\hline & 1.0 & 103.95 \\
\hline & 1.2 & 85.05 \\
\hline & 1.6 & 64.35 \\
\hline & 2.0 & 45.90 \\
\hline
\end{tabular}

Table 2. Solvent stability of protease. Residual enzyme activity (\%) before the solvent mixing was considered as $100 \%$. Relative to the residual activity of the distilled water at each day was kept as control to calculate the residual activity of five tested organic solvent

\begin{tabular}{|c|c|c|c|c|c|c|}
\hline \multirow[b]{2}{*}{ Sr. No. } & \multirow[b]{2}{*}{ Solvents } & \multirow[b]{2}{*}{$\log P$ value } & \multicolumn{4}{|c|}{ Residual enzyme activity (\%) after incubation (days) } \\
\hline & & & 0 & 1 & 3 & 5 \\
\hline 1 & Distilled water & & 100 & 98.33 & 96.99 & 95.67 \\
\hline 2 & DMSO & -1.35 & 100 & 93.66 & 88.78 & 85.36 \\
\hline 3 & Methanol & -0.82 & 100 & 82.21 & 75.99 & 71.33 \\
\hline 4 & Butanol & 0.83 & 100 & 81.19 & 72.66 & 68.99 \\
\hline 5 & Benzene & 2.45 & 100 & 79.56 & 72.33 & 67.73 \\
\hline 6 & n-Hexane & 3.6 & 100 & 99.33 & 95.79 & 92.48 \\
\hline
\end{tabular}

Table 3. Stability of protease in the presence of $0.7 \%$ laundry detergents. Activity of protease without the detergent was considered as $100 \%$ Residual enzyme activity (\%) at specific time interval in the presence of $0.7 \%$ commercial available laundry detergents

\begin{tabular}{|c|c|c|c|c|c|c|}
\hline $\begin{array}{l}\text { Detergent treatment } \\
\text { time }(\mathrm{min})\end{array}$ & $\begin{array}{l}\text { Control } \\
\text { (Without detergent) }\end{array}$ & Ariel & Rin & Surf excel & Tide & Wheel \\
\hline 0 & 100.00 & 100.00 & 100.00 & 100.00 & 100.00 & 100.00 \\
\hline 15 & 98.30 & 93.66 & 91.33 & 90.99 & 90.10 & 95.68 \\
\hline 30 & 95.57 & 89.10 & 84.93 & 84.42 & 83.99 & 90.33 \\
\hline 60 & 92.29 & 81.33 & 77.66 & 76.67 & 75.45 & 83.23 \\
\hline
\end{tabular}




\section{Compatibility of Protease with Commercial Detergents}

Good detergents stability was testified in the $0.7 \%$ concentration of each detergent. The enzyme was more compatible with Wheel and Ariel detergent as there was a greater than $80 \%$ activity after $60 \mathrm{~min}$. Moreover, protease stability in all the detergent was more than $84 \%$ after 30 min (Table 3). Negligible loss of activity in the control is evident due to the prolong shaking.

\section{Digestion of Natural Proteins}

The result of dehairing in goat hide in $2 \mathrm{~h}$ was remarkable. The visible difference of dehairing between enzyme treated and control hide can be observed (Fig. 6). Blood stain in fabric was lessened gradually with prolong incubation and removed within $2 \mathrm{~h}$ by enzyme treatment (Fig. 7).

\section{Discussion}

Hot spring is the bio-prosperity sink of the thermophiles and industrial important themoenzyme. Recently, culture-independent methods revealed the presence of many enzyme producing bacteria in the Indian subcontinent's hot springs (López-López et al., 2013; Ghelani et al., 2015; Mangrola et al., 2015). Thermophilic microorganisms have the adaptability to survive in harsh environmental conditions. The enzymes from thermophiles hold the structural secrets to remains stable at elevated temperature (Panda et al., 2013). The strain Bacillus cohnii was isolated from the less explored Unnai hot spring, where the temperature usually reported between $57^{\circ} \mathrm{C}$ to $61^{\circ} \mathrm{C}$. Earlier, thermophilic protease producing Bacillus licheniformis was reported from the Unnai hot spring (Dudhagara et al., 2014). Bacillus species are attractive industrial tools for a variety of reasons, including their high growth rates leading to short fermentation cycle times, their capacity to secrete proteins into the extracellular media and the Generally Regarded As Safe (GRAS) status with the food and drug administration (Manikandan et al., 2014).

The relationship between growth and enzyme secretion has been well studied in Bacillus species with maximum secretion reported in early stationary phase (Patel et al., 2005; Karan et al., 2011), which is concur with our result. Enzyme activity in late stationary phase and decline phase was remarkable; suggest the excellent structural stability of theenzymeand remains unfolded for prolong time. Use of the crude and partially purified enzymes is preferred over purified preparation to avoid the cost of purification and make the processes commercially viable. Recently, the applications of surfactant and detergent compatible crude protease from Bacillusmojavensis have been studied (Anissa et al., 2010).
The optimum $\mathrm{pH}$ and temperature for caseindegrading activity were 9.0 and $50^{\circ} \mathrm{C}$ respectively. It is indicative of alkaline and moderately thermoactive the nature of enzyme (Kirankumar et al., 2009). The $\mathrm{pH}$ and temperature optimum of protease is quite better than the alkaline protease of spring isolate Bacillus species (Badhe et al., 2009). The Salt-independent catalytic activity is suggestive of the cations in dependent thermostability nature of the enzyme. A good catalytic activity with various concentration of substrate is well suitable for the many industrial processes.

Stability at the various $\mathrm{pH}$, temperature and salt concentration is the key properties to explore the enzyme at industrial scale. The results of stability study correspond to earlier reports (Nejad et al., 2010; Nascimento and Martins, 2006). The enzyme exhibited good solvent tolerance to all the tested organic solvent. Almost similar stability trends for proteases in the presence of various organic solvents were reported in Pseudomonas aeruginosa and Bacillus licheniformis (Gupta and Khare, 2006; Sareen and Mishra, 2008). However, the effect of organic solvents on protease activity differs depending on types of protease and bacterial strains. The protease may be solvent stable because of the replacement of some water molecules in an enzyme with organic molecules leads to stabilizing the structure of the enzyme (Ghorbel et al., 2003).

The enzyme preparation exhibited the dehairing in goat hide reveals the keratinolytic nature of theenzyme. A similar application was evaluated in hot spring isolate Bacillus subtilis (Priyaand Archana, 2008). This finding is crucial in enzymatic dehairing of hide in leather industries. The enzyme may have an impending application as a dehairing agent (Vijay Kumar et al., 2011). The result of blood destaining with theprotease in $2 \mathrm{~h}$ supports the impending ecofriendly application (Rao et al., 2009).

\section{Conclusion}

Hot spring is the rich source of the protease producing bacteria. The isolate can growth at alkaline $\mathrm{pH}$ and elevated temperature so contamination free system can be designed for mass production of protease. The partial purified protease from the Bacillus cohnii was found thermostable alkali stable and clearly indicate the robust nature and good stability in the presence of wide range of physical and chemical parameter. Additionally, suitable solvent stability along with compatibility with detergents proved the extreme character of the enzyme. It is a valuable enzyme and can be utilized for the large-scale processes at a leather processing. Enzyme holds remarkable catalysis in harsh condition suggest the impending application in hide dehairing and detergent additives. 


\section{Funding Information}

The authors have no support or funding to report.

\section{Author's Contributions}

Pravin R Dudhgara: Designed the research plan and concept, Conduct the study and complete the dataanalysis, Prepared the manuscript, Communicating the manuscript.

Sunil Bhavsar: Take part in all the experiments starting from sampling to result of each experiments and performed the data analysis.

Anjana Ghelani: Participate and coordinate the in experiments, Reporting the result and collection of data, Manuscript preparation and correction.

\section{Ethics}

This article is original and contains unpublished material. The corresponding author confirms that all of the other authors have read and approved the manuscript and no ethical issues involved.

\section{References}

Adams, M.W.W. and R.M. Kelly, 1998. Finding and using hyperthermophilic enzymes. Trends Biotechnol, 16: 329-332. DOI: $10.1016 / \mathrm{S} 0167-7799(98) 01193-7$

Anissa, H., A. Rym, B. Ali, H. Noomen and S.K. Alya et al., 2009. Two detergent stable alkaline serine-proteases from Bacillus mojavensis A21: Purification, characterization and potential application as a laundry detergent additive. Bioresource Technol., 100: 3366-3373. DOI: $10.1016 /$ j.biortech.2009.01.061

Anissa, H., A. Sellami-Kamoun, N. Fakhfakh-Zouari, N. Hmidet and M. Nasri, 2010. Characterization of detergent stable and feather degrading serine proteases from Bacillus mojavensis A21. Biochem. Eng. J., 51: 53-63. DOI: 10.1016/j.bej.2010.05.002

Badhe, R.V., S.L. Harer, R.K. Nanda, S.R. Badhe and S.J. Jangam et al., 2009. Purification and partial characterization of thermostable serine alkaline protease from a newly isolated Bacillus species HSRB08 from hotspring. Hindustan Antibiotics Bull., 51: 9-16. PMID: 21268554

Banerjee, U.C., R.K. Sani, W. Azmi and R. Soni, 1999. Thermostable alkaline protease from Bacillus brevis and its characterization as a laundry detergent additive. Process Biochem., 35: 213-219. DOI: $10.1016 /$ S0032-9592(99)00053-9
Dudhagara, P., S. Bhavasar, A. Ghelani and S. Bhatt, 2014. Isolation, characterization and investing the industrial applications of thermostable and solvent tolerant serine protease from hot spring isolated thermophililic Bacillus licheniformis $\mathrm{U}_{1}$. Int. J. Applied Sci. Biotechnol., 2: 75-82. DOI: $10.3126 /$ ijasbt.v2i1.9519

Geok, L.P., C.N.A. Razak, R.N.Z.A. Rahman, M. Basri and A.B. Salleh, 2003. Isolation and screening of an extracellular organic solvent-tolerant protease producer. Biochem. Eng. J., 13: 73-77. DOI: $10.1016 / \mathrm{S} 1369-703 \mathrm{X}(02) 00137-7$

Ghelani, A., R. Patel, A. Mangrola and P. Dudhagara, 2015. Cultivation-independent comprehensive survey of bacterial diversity in Tulsi Shyam Hot Springs, India. Genomics Data, 4: 54-56. DOI: $10.1016 /$ j.gdata.2015.03.003

Ghorbel, B., A. Kamoun and M. Nasri, 2003. Stability studies of protease from Bacillus cereus BG1. Enzyme Microbial Technol., 32: 513-518. DOI: $10.1016 / \mathrm{S} 0141-0229(03) 00004-8$

Gupta, A. and S.K. Khare, 2006. A protease stable in organic solvents from solvent tolerant strain of Pseudomonas aeruginosa. Bioresource Technol., 97: 1788-1793.

DOI: 10.1016/j.biortech.2005.09.006

Gupta, R, Q.K. Beg and P. Lorenz, 2002. Bacterial alkaline proteases: Molecular approaches and industrial applications. Applied Microbiol. Biotechnol., 59: 15-32. DOI: $10.1007 / \mathrm{s} 00253-002-0975-\mathrm{y}$

Hagihara, B., 1958. The Enzymes. 4th Edn., Academic press Inc., New York.

Haki, G.D. and S.K. Rakshit, 2003. Developments in industrially important thermostable enzymes: A review. Bioresour Technol., 89: 17-34. DOI: $10.1016 / \mathrm{S} 0960-8524(03) 00033-6$

Hazem, A., A.Q. Farouk and K.Y. Tahani, 2012. A novel neutral protease from thermophilic Bacillus strain HUTBS62. J. Biosci. Biotechnol., 1: 117-123.

Hough, D.W. and M.J. Danson, 1999. Extremozymes. Current Opinion Chem. Biol., 3: 39-46. DOI: $10.1016 /$ S1367-5931(99)80008-8

Karan, R., S.P. Singh, S. Kapoor and S.K. Khare, 2011. A novel organic solvent tolerant protease from a newly isolated Geomicrobium sp. EMB2 (MTCC 10310): Production optimization by response surface methodology. New Biotechnol., 28: 136145. DOI: $10.1016 /$ j.nbt.2010.10.007

Kirankumar, D., R. Tatineni, R.N. Vellanki, S. Rachcha and N. Anabrolu et al., 2009. Purification and characterization of a solvent and detergent-stable novel protease from Bacillus cereus. Microbiol. Res., 164: 383-390.

DOI: 10.1016/j.micres.2007.04.005 
López-López, O., M.E. Cerdán and M.I. González-Siso, 2013. Hot spring metagenomics. Life, 2: 308-320. DOI: $10.3390 /$ life 3020308

Mangrola, A.V., P. Dudhagara, P. Koringa, C.G. Joshi and R.K. Patel, 2015. Shotgun metagenomic sequencing based microbial diversity assessment of Lasundra hot spring, India. Genomics Data, 4: 73-75. DOI: 10.1016/j.gdata.2015.03.005

Manikandan, S., P. Kavitha and A. Panneerselvam, 2014. Isolation, optimization and characterization of alkaline protease producing bacteria from collagen layer of decaying skin (sheep upper) leather industry. World J. Pharmaceutical Res., 3: 1611-1626.

Maurer, K.H., 2004. Detergent proteases. Current Opinion Biotechnol., 15: 330-334.

DOI: 10.1016/j.copbio.2004.06.005

Nascimento, W.C.A.D. and M.L.L. Martins, 2006. Studies on the stability of protease from Bacillus sp. and its compatibility with commercial detergent. Braz. J. Microbiol., 37: 307-311. DOI: $10.1590 / \mathrm{S} 1517-83822006000300020$

Nejad, Z.G., S. Yaghmaei and R.H. Hosseini, 2010. Production of extracellular protease and determination of optimal condition by Bacillus Licheniformis BBRC 100053. Chem. Eng. Trans., 21: 1447-1452.

Olajuyigbe, F.M. and A.O. Kolawole, 2011. Purification and partial characterization of a thermostable alkaline protease from Bacillus licheniformis LHSB05 isolated from hot spring. Afr. J. Biotechnol., 10: 11703-11710. DOI: 10.5897/AJB11.717

Paliwal, N., S.P. Singh and S.K. Garg, 1994. Cationinduced thermal stability of an alkaline protease from a Bacillus sp. Bioresour Technol., 50: 209-211. DOI: 10.1016/0960-8524(94)90091-4

Panda, M.K., M.K. Sahu and K. Tayung, 2013. Isolation and characterization of a thermophilic Bacillus sp. with protease activity isolated from hot spring of Tarabalo, Odisha, India. Iranian J. Microbiol., 5: 159-165. PMID: 23825735
Pant, G., A. Prakash, J.V.P. Pavani, S. Bera and G.V.N.S. Deviram et al., 2015. Production, optimization and partial purification of protease from Bacillus subtilis. J. Taibah Uni. Sci., 9: 50-55. DOI: $10.1016 /$ j.jtusci.2014.04.010

Patel, R., M. Dodia and S.P. Singh, 2005. Extracellular alkaline protease from a newly isolated haloalkaliphilic Bacillus sp.: Production and optimization. Process Biochem., 40: 3569-3575. DOI: $10.1016 /$ j.procbio.2005.03.049

Priya, P. and G. Archana, 2008. Hide depilation and feather disintegration studies with keratinolytic serine protease from a novel Bacillus subtilis isolate. Applied Microbiol. Biotechnol., 78: 643-650. DOI: $10.1007 / \mathrm{s} 00253-008-1355-\mathrm{z}$

Rao, C.S., T. Sathish, P. Ravichandra and R.S. Prakasham, 2009. Characterization of thermo- and detergent stable serine protease from isolated Bacillus circulans and evaluation of eco-friendly applications. Process Biochem., 44: 262-268. DOI: $10.1016 /$ j.procbio.2008.10.022

Sareen, R. and P. Mishra, 2008. Purification and characterization of organic solvent stable protease from Bacillus licheniformis RSP-09-37.Applied Microbiol. Biotechnol., 79: 399-405. DOI: $10.1007 / \mathrm{s} 00253-008-1429-\mathrm{y}$

Seatovic, S., L. Gligic, Z. Radulovic and M.R. Jankov, 2004. Purification and partial characterization of superoxide dismutase from the thermophilic bacteria Thermothrix sp. J. Serbian Chem. Society, 69: 9-16.

Vijay Kumar, E., M. Srijana, K. Kiran Kumar, N. Harikrishna and G. Reddy, 2011. A novel serine alkaline protease from Bacillus altitudinis GVC11 and its application as a dehairing agent. Bioprocess Biosyst. Eng., 34: 403-409. DOI: $10.1007 / \mathrm{s} 00449-010-0483-\mathrm{x}$

Wei, Z., D. Cha, G. Cheng, Q. Peng and P. Shen, 2007. Purification and characterization of a thermostable protease from a newly isolated Geobacillus $s p$. YMTC 1049. Enzyme Microbial Technol., 40: 1592-1597. DOI: 10.1016/j.enzmictec.2006.11.007 